\title{
Six Months of Treatment with the Endoscopic Duodenal-Jejunal Bypass Liner Does Not Lead to Decreased Systemic Inflammation in Obese Patients with Type 2 Diabetes
}

Citation for published version (APA):

de Jonge, C., Rensen, S. S., D'Agnolo, H. M., Bouvy, N. D., Buurman, W. A., \& Greve, J. W. (2014). Six Months of Treatment with the Endoscopic Duodenal-Jejunal Bypass Liner Does Not Lead to Decreased Systemic Inflammation in Obese Patients with Type 2 Diabetes. Obesity Surgery, 24(2), 337-341. https://doi.org/10.1007/s11695-013-1154-1

Document status and date:

Published: 01/02/2014

DOI:

10.1007/s11695-013-1154-1

Document Version:

Publisher's PDF, also known as Version of record

Document license:

Taverne

Please check the document version of this publication:

- A submitted manuscript is the version of the article upon submission and before peer-review. There can be important differences between the submitted version and the official published version of record. People interested in the research are advised to contact the author for the final version of the publication, or visit the DOI to the publisher's website.

- The final author version and the galley proof are versions of the publication after peer review.

- The final published version features the final layout of the paper including the volume, issue and page numbers.

Link to publication

\footnotetext{
General rights rights.

- You may freely distribute the URL identifying the publication in the public portal. please follow below link for the End User Agreement:

www.umlib.nl/taverne-license

Take down policy

If you believe that this document breaches copyright please contact us at:

repository@maastrichtuniversity.nl

providing details and we will investigate your claim.
}

Copyright and moral rights for the publications made accessible in the public portal are retained by the authors and/or other copyright owners and it is a condition of accessing publications that users recognise and abide by the legal requirements associated with these

- Users may download and print one copy of any publication from the public portal for the purpose of private study or research.

- You may not further distribute the material or use it for any profit-making activity or commercial gain

If the publication is distributed under the terms of Article 25fa of the Dutch Copyright Act, indicated by the "Taverne" license above, 


\title{
Six Months of Treatment with the Endoscopic Duodenal-Jejunal Bypass Liner Does Not Lead to Decreased Systemic Inflammation in Obese Patients with Type 2 Diabetes
}

\author{
Charlotte de Jonge $\cdot$ Sander S. Rensen $\cdot$ \\ Hedwig M. A. D'Agnolo • Nicole D. Bouvy • \\ Wim A. Buurman • Jan Willem M. Greve
}

Published online: 20 December 2013

(C) Springer Science+Business Media New York 2013

\begin{abstract}
Obesity is associated with chronic low-grade systemic inflammation. Bariatric surgery has been shown to reduce this inflammation. Here, the effect of a nonsurgical bariatric technique, the duodenal-jejunal bypass liner (DJBL), on systemic inflammation was investigated. Seventeen obese patients with type 2 diabetes were treated with the DJBL for 6 months. Plasma C-reactive protein (CRP), myeloperoxidase (MPO), interleukin-6 (IL-6), and tumor necrosis factor alpha $(\mathrm{TNF}-\alpha)$ were determined prior to and during DJBL treatment. Three months after initiation of DJBL treatment, TNF- $\alpha$ levels had increased from $1.8 \pm 0.1$ to $2.1 \pm 0.1 \mathrm{pg} / \mathrm{mL}$, whereas IL-6
\end{abstract}

C. de Jonge · S. S. Rensen • H. M. A. D'Agnolo • N. D. Bouvy •

W. A. Buurman

Department of General Surgery and NUTRIM School for Nutrition, Toxicology and Metabolism, Maastricht University Medical Center,

P. Debyelaan 25, 6229 HX Maastricht, The Netherlands

C. de Jonge

e-mail: c.dejonge@maastrichtuniversity.nl

S. S. Rensen

e-mail: s.rensen@maastrichtuniversity.nl

H. M. A. D'Agnolo

e-mail: H.DAgnolo@mdl.umcn.nl

N. D. Bouvy

e-mail: n.bouvy@maastrichtuniversity.nl

W. A. Buurman

e-mail: w.buurman@maastrichtuniversity.nl

C. de Jonge $\cdot$ J. W. M. Greve

Department of General Surgery, Atrium Medical Center Parkstad,

Henri Dunantstraat 5, 6419 PC Heerlen,

The Netherlands

J. W. M. Greve $(\bowtie)$

Department of General Surgery, Atrium Medical Center Parkstad,

PO Box 4446, 6401 CX Heerlen,

The Netherlands

e-mail: j.greve@atriummc.nl increased from $2.7 \pm 0.3$ to $4.0 \pm 0.5 \mathrm{pg} / \mathrm{mL}$ (both $p<0.05$ ). CRP and MPO also increased, though the differences were not significant. After 6 months, the levels of all parameters were similar to baseline levels (CRP, $4.2 \pm 0.6 \mathrm{mg} / \mathrm{L}$; TNF- $\alpha, 2.0 \pm$ $0.1 \mathrm{pg} / \mathrm{mL} ; \mathrm{IL}-6,3.5 \pm 0.5 \mathrm{pg} / \mathrm{mL} ; \mathrm{MPO}, 53.6 \pm \mathrm{ng} / \mathrm{mL}$; all $p=\mathrm{ns}$ compared to baseline). In the current study, 6 months of endoscopic DJBL treatment did not lead to decreased systemic inflammation.

Keywords Bariatric surgery $\cdot$ Inflammation ·

Duodenal-jejunal exclusion

\section{Background}

Obesity is associated with chronic low-grade systemic inflammation $[1,2]$. This inflammatory state has been suggested to originate, at least for an important part, from the adipose tissue $[3,4]$. Visceral adipose tissue, in particular, secretes several pro-inflammatory cytokines, called adipokines. In obesity, adipose tissue expansion leads to an imbalance in adipokine production contributing to the local and systemic inflammation typical of obese patients [3].

The obesity-associated pro-inflammatory state is suggested to be a crucial pathogenic component in the development of obesity-related comorbid conditions such as type 2 diabetes [5-7]. Bariatric surgery is effective in treating both obesity and type 2 diabetes [ $[8,9]$. In addition, it is often accompanied by a decrease of the low-grade inflammation [10-12]. Therefore, improvement of the inflammatory state has been suggested to underlie the resolution of type 2 diabetes after bariatric surgery $[11,13]$.

We here investigated the effect of the endoscopic duodenaljejunal bypass liner (DJBL) on systemic inflammation. The DJBL is a nonsurgical bariatric technique previously shown to 
be effective in treating obesity and type 2 diabetes [14-16]. To obtain more insight into the possible involvement of inflammation in this improvement, plasma C-reactive protein (CRP), myeloperoxidase (MPO), interleukin 6 (IL-6), and tumor necrosis factor alpha (TNF- $\alpha$ ) were determined before and during DJBL treatment.

\section{Methods}

Patients

Seventeen patients with obesity and type 2 diabetes were included in two centers: the Maastricht University Medical Center, Maastricht, the Netherlands, and the Atrium Medical Center Parkstad, Heerlen, the Netherlands. Inclusion criteria were age between 18 and 65 years, body mass index (BMI) between 30 and $50 \mathrm{~kg} / \mathrm{m}^{2}$, duration of type 2 diabetes less than 10 years, and $\mathrm{HbA} 1 \mathrm{c}$ between 7.5 and $10.0 \%$. Main exclusion criteria were use of anti-inflammatory drugs or history of inflammatory diseases, use of weight loss medication, pregnancy or the intention to become pregnant during the course of the study, and exclusion criteria regarding safety of DJBL placement or DJBL compatibility. The study was approved by the Medical Ethics Committee of each center and conducted according to the revised version of the Declaration of Helsinki (October 2008, Seoul). Written informed consent was obtained from every patient before study participation.

\section{The DJBL}

The DJBL is a 60 -cm-long impermeable liner which has been developed to mimic the intestinal bypass component of the Roux-en-Y gastric bypass in a nonsurgical way. The DJBL was delivered and retrieved endoscopically as previously described [15]. In brief, a gastroduodenal endoscopy was performed under general anesthesia. A guide wire was placed into the duodenum over which the encapsulated DJBL was directed through the pylorus into the duodenal bulb. The DJBL was advanced into the small intestine, followed by deployment of the anchor in the duodenal bulb. Correct positioning and patency of the DJBL were verified under fluoroscopy. No abnormalities were observed. For safety reasons, liquid nutrition was advised during the first week postimplantation. In addition, patients were provided standard of care bariatric nutritional counseling.

After 24 weeks, all patients had completed the treatment, and the DJBL was explanted as previously described [15]. In brief, explantation was performed endoscopically under general anesthesia using a custom retrieval system containing a grasper and a retrieval hood. No patient showed any sign of malfunction or malposition of the DJBL. By grasping the wires on the anchor, the anchor collapsed and was pulled into the retrieval hood on top of the endoscope. After verification of the collapsed anchor by fluoroscopy, the device was removed.

\section{Study Design and Plasma Analysis}

Patients were studied on three occasions, i.e., within 1 month prior to (D0) and at 3 and 6 months after initiation of DJBL treatment (M3 and M6, respectively). At each time point, patients visited the outpatient clinic where body weight was determined and fasting venous blood samples were obtained, immediately centrifuged, and stored at $-80{ }^{\circ} \mathrm{C}$ until further analysis.

To determine plasma levels of CRP, a high-sensitivity sandwich enzyme-linked immunosorbent assay was used as previously described [17]. Plasma MPO, TNF- $\alpha$, and IL-6 concentrations were determined using commercially available enzyme-linked immunosorbent assays according to the manufacturer's protocol (MPO: kindly provided by Hycult Biotechnology, Uden, the Netherlands; TNF- $\alpha$ and IL-6: both high-sensitive assays from R \& D Systems, Minneapolis, $\mathrm{MN})$.

\section{Statistical Analysis}

Statistical analyses were performed using GraphPad Prism 5.0. Longitudinal changes were tested using the Wilcoxon signed rank test. A $p$ value of $<0.05$ was considered statistically significant. Data are presented as mean and standard error of the mean (SEM).

\section{Results}

Effects of the DJBL on Obesity

Baseline characteristics of the study population can be found in Table 1. As shown, patients had an average body weight of $116.0 \pm 5.8 \mathrm{~kg}$ with a mean BMI of $37.0 \pm 1.3 \mathrm{~kg} / \mathrm{m}^{2}$ at

Table 1 Baseline characteristics of the study population

Data are shown as mean \pm SEM or no (percentage)

\begin{tabular}{ll}
\hline & $N=17$ \\
\hline Age (years) & $51 \pm 2$ \\
Sex (male) & $14(82.4)$ \\
Weight $(\mathrm{kg})$ & $116.0 \pm 5.8$ \\
BMI $\left(\mathrm{kg} / \mathrm{m}^{2}\right)$ & $37.0 \pm 1.3$ \\
HbA1c $(\%)$ & $8.4 \pm 0.2$ \\
CRP $(\mathrm{mg} / \mathrm{L})$ & $5.3 \pm 1.1$ \\
TNF- $\alpha(\mathrm{pg} / \mathrm{mL})$ & $1.8 \pm 0.1$ \\
$\mathrm{IL}-6(\mathrm{pg} / \mathrm{mL})$ & $2.7 \pm 0.3$ \\
MPO $(\mathrm{ng} / \mathrm{mL})$ & $45.5 \pm 4.3$ \\
\hline
\end{tabular}


baseline. Three months after DJBL implantation, body weight had decreased to $105.3 \pm 5.5 \mathrm{~kg}$, corresponding with a reduction of excess weight of $25.2 \pm 3.1 \%$ and a BMI reduction of $3.4 \pm 0.4 \mathrm{~kg} / \mathrm{m}^{2}(p<0.05)$. After 6 months, at the time of device explantation, mean body weight had further decreased to $103.3 \pm 5.5 \mathrm{~kg}$ resulting in a total weight loss of $12.7 \pm 1.3 \mathrm{~kg}$, which corresponds to an excess weight loss of $29.8 \pm 3.5 \%$ and a BMI reduction of $4.1 \pm 0.4 \mathrm{~kg} / \mathrm{m}^{2}(p<0.05$ when compared to baseline).

Effect of DJBL Treatment on Systemic Inflammation as Indicated by Plasma CRP Levels

To obtain insight into the effects of DJBL treatment on systemic inflammation, plasma concentrations of CRP were determined before and at 3 and 6 months after DJBL implantation. As shown in Fig. 1a, at baseline, the mean CRP level was marginally elevated as typical for the low-grade systemic inflammatory state in obese patients $(5.3 \pm 1.1 \mathrm{mg} / \mathrm{L})$ [1]. Three months after implantation of the DJBL, plasma CRP had slightly but nonsignificantly increased to $7.9 \pm 1.3 \mathrm{mg} / \mathrm{L}$ $(p=0.06)$. After 6 months, the mean concentration of plasma CRP had decreased to baseline levels $(4.2 \pm 0.6 \mathrm{mg} / \mathrm{L}, p<0.05$ compared to month 3 ).

Changes in TNF- $\alpha$ and IL-6 Concentrations after DJBL Implantation

At baseline, patients showed a mean plasma TNF- $\alpha$ concentration of $1.8 \pm 0.1 \mathrm{pg} / \mathrm{mL}$. The mean IL-6 concentration was $2.7 \pm 0.3 \mathrm{pg} / \mathrm{mL}$. Three months after implantation of the DJBL, plasma levels of both TNF- $\alpha$ and IL- 6 were slightly but significantly increased to $2.1 \pm 0.1$ and $4.0 \pm 0.5 \mathrm{pg} / \mathrm{mL}$, respectively (both $p<0.05$ ). After 6 months, the concentrations of TNF- $\alpha$ and IL- 6 were no longer significantly different from the baseline levels (TNF- $\alpha, 2.0 \pm 0.1 \mathrm{pg} / \mathrm{mL} ; p=0.13$; and IL$6,3.5 \pm 0.5 \mathrm{pg} / \mathrm{mL}, p=0.12$ ).

Effect of DJBL Treatment on Neutrophil Activation as Assessed by MPO Plasma Concentrations

As previously shown, neutrophil activation as reflected by plasma MPO levels is increased in obese patients [18]. We here evaluated the effect of DJBL treatment on concentrations of plasma MPO. At baseline, the mean plasma MPO concentration was $45.5 \pm 4.3 \mathrm{ng} / \mathrm{mL}$. After initiation of DJBL treatment, this concentration increased to $67.9 \pm 10.5 \mathrm{ng} / \mathrm{mL}(p=$ 0.06). After 6 months, mean MPO concentrations were decreased again and not significantly different from baseline levels ( $53.6 \pm \mathrm{ng} / \mathrm{mL}, p=0.82$ compared to baseline).

\section{Conclusion}

In obesity, particularly, the abdominal or visceral adipose tissue depots secrete increased amounts of pro-inflammatory cytokines such as IL- 6 and TNF- $\alpha$. These cytokines are, in turn, important stimulators of the hepatic production of the acute-phase protein CRP, thereby establishing the chronic low-grade inflammatory status characterizing obese subjects $[3,4]$. In addition, increased neutrophil activation as indicated by elevated MPO levels, a neutrophil secretion product, has been observed in obese patients [18]. We here investigated the effect of a nonsurgical bariatric technique, the endoscopic
Fig. 1 The effect of DJBL treatment on plasma levels of CRP, TNF- $\alpha$, IL-6, and MPO. a Plasma CRP levels at baseline and 3 and 6 months after implantation of the DJBL. b Plasma levels of TNF- $\alpha$ at baseline and 3 and 6 months postimplantation. c Plasma concentrations of IL- 6 obtained at baseline and 3 and 6 months after implantation of the DJBL. dMPO plasma concentrations prior to and 3 and 6 months after initiation of DJBL treatment. An asterisk (*) indicates $p<0.05$
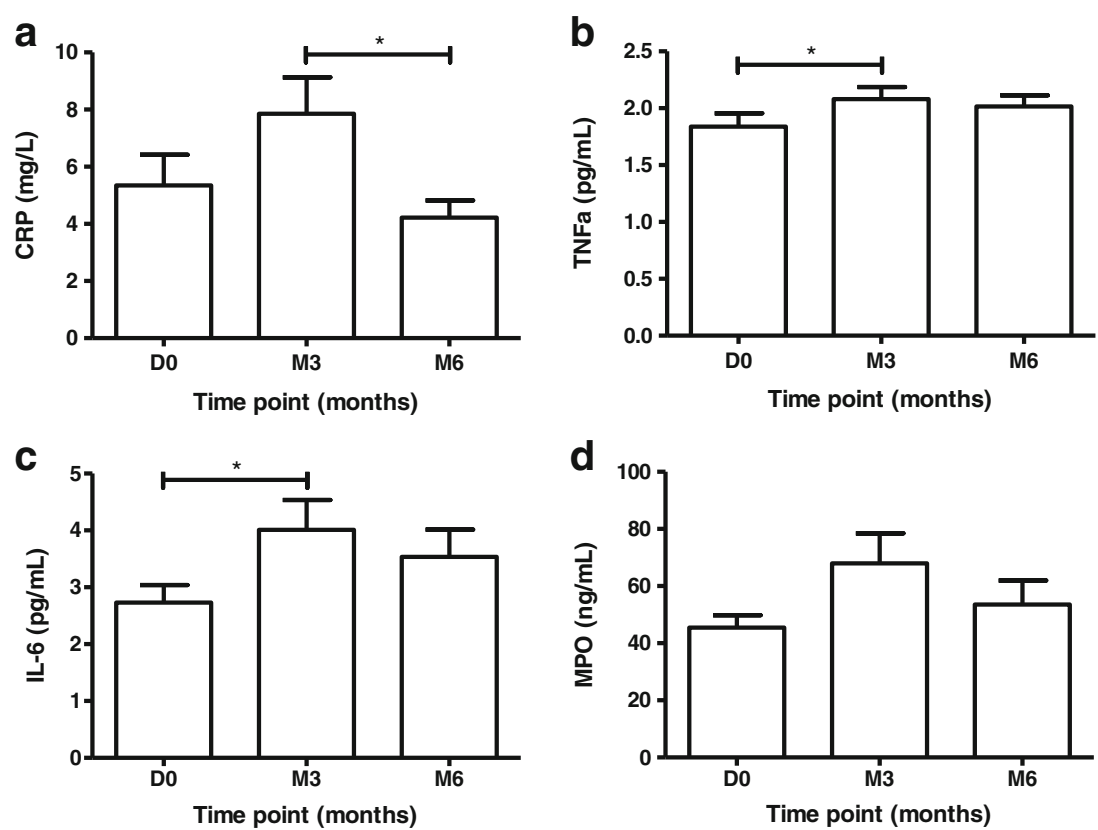
DJBL on inflammatory plasma parameters, and found a transient increase after 3 months of treatment, followed by a return to baseline levels after 6 months.

On the long term, reduction of the obesity-related chronic low-grade inflammatory profile has been observed after bariatric surgery [10-12]. However, contradicting results have been found within weeks to months after the procedures [10, $12,19]$. Miller et al. evaluated early changes in inflammatory biomarkers after Roux-and-Y gastric bypass and observed no changes in IL- 6 and TNF- $\alpha$ levels. CRP levels were only decreased after 6 months. A study by van Dielen et al. revealed elevated levels of inflammatory mediators for at least 3 months after gastric restrictive surgery. Rao performed a meta-analysis evaluating CRP, TNF- $\alpha$, and IL-6 levels at 1,3 , 6 , and 12 months after bariatric surgery and showed decreased CRP levels at all time points. However, TNF- $\alpha$ levels seemed to remain stable over time, and IL-6 levels dropped after 3 months. A possible explanation for the transiently increased inflammatory state that we observed might be an enhanced metabolic stress response initiated by relative starvation. In anorectic patients, elevated inflammatory parameters have been found. Weight loss after bariatric surgery can be considered comparable to chronic starvation, probably contributing to the increased inflammatory profile [19]. In addition, the DJBL itself might trigger the immune system: the presence of an inflammatory reaction has been described at the anchor site after 3 months of DJBL treatment [20]. Notably, the observed enhanced low-grade inflammation was only temporary. Significant differences from baseline concentrations as seen after 3 months were absent after 6 months of DJBL treatment. Moreover, with regard to the observed decrease of CRP levels after 6 months, it is tempting to speculate that a trend is initiated and that patients could potentially benefit from longer treatment duration. This suggestion finds support in the publication of van Dielen et al., which also described increased CRP levels at 3 months after gastric restrictive surgery, with a subsequent decrease when weight loss continued [19].

Remarkably, previous studies with the DJBL have demonstrated rapid improvement of type 2 diabetes [14, 15]. This was confirmed in our previous study investigating the effect of DJBL treatment on type 2 diabetes and related hormones which revealed rapid hormonal changes and improvement of type 2 diabetes [16]. It can be speculated that reduced inflammation might mediate this improvement, since type 2 diabetes and chronic low-grade systemic inflammation seem strongly linked [5-7], and previous research performed after bariatric surgery is supportive of this theory $[11,13]$. However, the current data do not support this suggestion; no improvement of inflammatory parameters was observed. Importantly, it should be taken into account that the group of patients studied in the current manuscript had relatively low levels of inflammatory parameters at baseline [11-13]. Therefore a tremendous improvement of the inflammatory status was not to be expected in these patients. In addition, the sample size of the current study is rather small. Nevertheless, it is the first data available on the effect of DJBL treatment of inflammatory parameters, and further studies in patients with a larger number of patients and/or with patients with a more pronounced inflammatory profile are warranted to more thoroughly investigate the effect of the DJBL on inflammation and elucidate the relation with type 2 diabetes. Additionally, this study lacks a control group of patients subjected to nutritional counseling alone. Interestingly, unpublished data comparing DJBL treatment in combination with nutritional counseling vs. nutritional counseling alone show inferior weight loss in the control group. Therefore, a mere nutritional effect is not expected.

Taken together, the data in the current study suggest that 6 months of endoscopic DJBL treatment is not associated with reduced systemic inflammation in moderately obese subjects with type 2 diabetes. Nevertheless, it seems worthwhile to evaluate the effect of longer treatment duration in further studies as well as the effect of the DJBL in a larger group of patients with a more severe inflammatory profile.

Acknowledgments The authors would like to thank the patients contributing to this trial; the trial nurses Y. Wils and R. Nelissen; the students who helped conducting this research; Dr. R.J. de Ridder, Dr. G.H. Koek, and Dr. C.M. Bakker for their help with the DJBL procedures; and Dr. F.J. Verdam for her help regarding the study design.

Conflict of Interest N.D.B. received an open research grant from GI dynamics. J.W.G. is consultant for GI dynamics and received an open research grant and support for travel to meetings for the study or other purposes from GI dynamics. All other authors have no conflicts of interest relevant to this article.

\section{References}

1. Visser $M$ et al. Elevated C-reactive protein levels in overweight and obese adults. JAMA. 1999;282(22):2131-5.

2. Gregor MF, Hotamisligil GS. Inflammatory mechanisms in obesity. Annu Rev Immunol. 2011;29:415-45.

3. Ouchi $\mathrm{N}$ et al. Adipokines in inflammation and metabolic disease. Nat Rev Immunol. 2011;11(2):85-97.

4. Maachi M et al. Systemic low-grade inflammation is related to both circulating and adipose tissue TNFalpha, leptin and IL-6 levels in obese women. Int J Obes Relat Metab Disord. 2004;28(8):993-7.

5. Donath MY, Shoelson SE. Type 2 diabetes as an inflammatory disease. Nat Rev Immunol. 2011;11(2):98-107.

6. Cottam DR et al. The chronic inflammatory hypothesis for the morbidity associated with morbid obesity: implications and effects of weight loss. Obes Surg. 2004;14(5):589-600.

7. Kalupahana NS, Moustaid-Moussa N, Claycombe KJ. Immunity as a link between obesity and insulin resistance. Mol Aspects Med. 2012;33(1):26-34.

8. Sjostrom L et al. Lifestyle, diabetes, and cardiovascular risk factors 10 years after bariatric surgery. N Engl J Med. 2004;351(26):268393.

9. Buchwald $\mathrm{H}$ et al. Weight and type 2 diabetes after bariatric surgery: systematic review and meta-analysis. Am J Med. 2009;122(3):24856. e5. 
10. Rao SR. Inflammatory markers and bariatric surgery: a metaanalysis. Inflamm Res. 2012;61(8):789-807.

11. Illan-Gomez F et al. Obesity and inflammation: change in adiponectin, C-reactive protein, tumour necrosis factor-alpha and interleukin-6 after bariatric surgery. Obes Surg. 2012;22(6):950-5.

12. Miller GD, Nicklas BJ, Fernandez A. Serial changes in inflammatory biomarkers after Roux-en-Y gastric bypass surgery. Surg Obes Relat Dis. 2011;7(5):618-24.

13. Kopp HP et al. Impact of weight loss on inflammatory proteins and their association with the insulin resistance syndrome in morbidly obese patients. Arterioscler Thromb Vasc Biol. 2003;23(6):1042-7.

14. Escalona A et al. Weight loss and metabolic improvement in morbidly obese subjects implanted for 1 year with an endoscopic duodenal-jejunal bypass liner. Ann Surg. 2012;255(6):1080-5.

15. Schouten $\mathrm{R}$ et al. A multicenter, randomized efficacy study of the EndoBarrier Gastrointestinal Liner for presurgical weight loss prior to bariatric surgery. Ann Surg. 2010;251(2):236-43.
16. de Jonge $\mathrm{C}$ et al. Endoscopic duodenal-jejunal bypass liner rapidly improves type 2 diabetes. Obes Surg. 2013. doi:10.1007/s11695-0130921-3.

17. van Dielen FM et al. Increased leptin concentrations correlate with increased concentrations of inflammatory markers in morbidly obese individuals. Int $\mathrm{J}$ Obes Relat Metab Disord. 2001;25(12):1759-66.

18. Nijhuis $J$ et al. Neutrophil activation in morbid obesity, chronic activation of acute inflammation. Obesity. 2009;17(11):2014-8.

19. van Dielen FM et al. Macrophage inhibitory factor, plasminogen activator inhibitor-1, other acute phase proteins, and inflammatory mediators normalize as a result of weight loss in morbidly obese subjects treated with gastric restrictive surgery. J Clin Endocrinol Metab. 2004;89(8):4062-8.

20. Tarnoff $\mathrm{M}$ et al. Chronic in-vivo experience with an endoscopically delivered and retrieved duodenal-jejunal bypass sleeve in a porcine model. Surg Endosc. 2008;22(4):1023-8. 